\title{
OBSTACLES ENCOUNTERED WHILE INTEGRATING LITERATURE IN TEACHING ENGLISH
}

\section{Yulnetri}

English Department of IAIN Batusangkar e-mail: ummuhanafi73@gmail.com

\begin{abstract}
Abstrak: This article depicts problems faced by High School teachers while using literature in teaching English. The data related to their broad views of using literature in the classroom were obtained from semi structured questionnaires as the preliminary data distributed to English teachers in Tanah Datar regency. As the result, by using purposive sampling technique ten of the teachers were selected to be the informants of the research. Then, in-depth interviews were conducted to the informants in order to find the obstacles encountered while integrating literature in their teaching of English. As the result, most of the informants found that using literature is interesting, however it is relatively disadvantageous because of several burdens, such as 1) Its difficult language, in terms of its complexity, its structure, vocabulary, poetic and unfamiliar diction, 2) inappropriacy with the students' level, 3) not suitable with the topics, 4) time management, 5) students' lack of pronunciation, 6) unavailable supporting tools, 7) limited resources, 8) students' unconfidence, and 9) unattractive poem materials.
\end{abstract}

Keyword : Obstacles, Integrating Literature, and Teaching English

\section{INTRODUCTION}

$\mathrm{L}$ iterature and language are closely related and this is a fact none can deny. Literature is constituted by language and it represents one of the most recurrent uses of language. Brumfit and Carter (1986: 1) already emphasized the role of literature as "an associate of language". It means talking about literature deals with talking about the language used in the literary work. Practically, it might be said that language can be taught through literature and vice versa. Moreover, there are three kinds of literature might be used in language teaching, such as poem as well as songs, prose (short stories, novelette, and novel), and drama.

Introducing literature into an ELT classroom can be beneficial for a wide variety of reasons. As Brumfit (2001) states, it can afford English language students the chance to know other cultures that might not be found in English language textbooks. Literature presents students with the opportunity to understand how the English language is used in various contexts and can convey genuine, authentic cultural enrichment whilst training the mind and sensibility (Parkinson \& Reid Thomas, 2000). 
However, using the literature in teaching English gets many challenges. In fact many teachers argue that it is difficult to teach English by using literary works. From the interview with the English teachers in Junior High Schools in Tanah Datar regency, it was found that just few of them who have ever used literature, such as songs, poetry, drama, short story and short movie, however, they have got difficulties in using it. Due to the suitability with students' vocabulary level, relevance with the topic and standard competences, and time management, the teachers finally were reluctant to use literature in the classroom.

Quite in line with that, many English students face difficulties in understanding the meaning of the text. They have problems in moving from basic decoding of texts towards fluency. These obstacles may include a lack of textual and cultural background knowledge, which is often regrettably glossed over in the classroom in favor of teaching information retrieval skills that "exclude the cultural values and identities, or expressive and aesthetic characteristic (Howatt \& Widdowson, 2004, p. 357). This runs the risk that many ELT students will be alienated or confused by the cultural content in authentic literature due to its not matching their own social and cultural schematic knowledge (Widdowson, 1990). If learners cannot understand or process authentic texts then, as Waring (2006: 1) observes, "the text is noise and frustrational... and not instructional but interfering with instruction".

Hence, this article aims at pinpointing the description of obstacles encountered by English teachers in using and or integrating literature. The writer begins with the benefits of using literature, and the factual obstacles faced by the English teachers Junior High Schools in Tanah Datar regency.

\section{Benefits of Using Literature in ELT Classroom}

Literature is considered as a potential tool for language learning purposes. Scholars in the field have proposed various advantages for the use of literature in EFL/ESL classes. The followings are a summary compiled from a number of experts' opinions that can be considered as the benefits of literature in EFL/ESL.

\section{Authenticity}

Literature provides authentic input for language learning (Ghosn, 2002; Shrestha, 2008). According to Maley (1989) literature deals with non-trivial things which are personally relevant to them. Authenticity is a criterion considered highly significant in the current literature in EFL/ESL which naturally exists in literary texts. It can especially be recognized in drama and novel. At first, drama has conversations, expressions of feelings, functional phrases, and contextualized expressions. Next, in novels, descriptive writing along with other types of writing adds to the imaginative nature of human and hence language is easily etched on our mind.

\section{Motivation}

Literary texts are very motivating due to its authenticity and the meaningful context it provides (Ghosn, 2002, Van, 2009). Literature deals with things which are interesting in nature and includes little if any uninteresting things (Maley, 1989a). Motivation is one of the elements which can drive the learners to go ahead. Motivation is especially achieved when students are exposed to what they really enjoy. Experience shows that students are highly motivated when they are exposed to literary texts for language learning purposes. 
3.Cultural/Intercultural Awareness and Globalization

Literature promotes cultural and intercultural awareness especially in the era of globalization (Tayebipour, 2009). In the era of globalization, there is a growing concern of universally shared needs and wants rather than individual needs. Since literature deals with universal concepts (Maley, 1989a), there is an urge to grab on literature as an input source for flourishing language learners' competence.

Globalization does not only relate in economy, politics, and sociology but also in language-related fields such as ELT. According to Maley (1989a), literature deals with universal concepts such as love, hatred, death, nature, etc that are common to all languages and cultures. The similarities and even differences between cultures and languages can further our understanding of the whole world.

\section{Intensive/Extensive Reading Practice}

Literature is good for extensive and intensive reading. Novels are good for extensive reading purposes. Students can be given a week just to go through a novel without extensive use of dictionary. Such a practice will double up their reading speed and also encourage meaning guessing in reading. Subsequently learners learn how to read a lot in a short period of time. On the other hand, the best literary text for intensive reading purposes can be poetry. Poetry is good for close analysis. In this way, students can be assigned to read each stanza closely to delve into the text and dig out hidden meaning expressed through literary elements such as metaphor, simile, allegory, etc. Intensive reading can lead the learners to extract deep meanings embedded in texts. 5. Sociolinguistic/Pragmatic Knowledge
Sociolinguistic and Pragmatic competence are two of the main components of the communicative competence models. Due to its authenticity, literature is equipped with sociolinguistic and pragmatic information. These two features are more related to 'appropriateness' in language use which can be found only in contextualized language such as literary texts especially in dramas and plays.

\section{Grammar and Vocabulary Mastery}

Arthur (1968) believes that syntactic knowledge and vocabulary enrichment can be accelerated through literary texts. Moreover, literature involves a profound range of vocabulary, dialogues and prose (Van, 2009). Literary texts are the major sources where complex structures such as dangling structure, inversion, subjunctives, etc occur. On the other hand, vocabulary knowledge can be expanded through considerable exposure to literary texts which treat both formal and informal language. Reading short stories and novels is a good exercise for enlarging one's vocabulary domain of knowledge.

\section{Language Skills}

Literature also deals with the development of language skills, such as reading, writing, speaking and listening (Stern, 2001, and Vandrick, 1996). For writing purposes, literature shows to set a good ground for writing practice. Having the learners complete a poem or short story in cloze form is very encouraging. Also we can have the students write the end of a story in their own words or narrate a story from the point of view of another character in a short story, novella, or novel. Other similar creative activities can be developed for writing practice.

For speaking purposes, the events in a poem, novel, or short story can be associated 
with the learners' own experience in real life. Such a practice paves the way for hot topics for discussion in language classes. Having the students freely reflect on the events and having them critically comment is also facilitative for advancing speaking proficiency.

For listening purposes, the learners can be exposed to the audio versions of the poems, short stories, or novels. Also the musical elements in poetry stimulate the learners' desire for approximating their speaking patterns to the native speaker norms by adhering to the principles of rhythm, rhyme, and intonation.

For reading purposes, as abovementioned, novel and poetry can provide good opportunities for extensive and intensive reading. Also it is good for practicing reading subskills including skimming, scanning, and finding the main ideas. Reading in literature is a combination of reading for enjoyment and reading for information. Therefore, it bridges the lacks in non-literary texts.

\section{Emotional Intelligence (EQ)}

Reading literary texts foster emotional intelligence (Ghosn, 2002). Daniel Goleman, the pioneer in EQ, believes that IQ and even multiple intelligences did not cater for this aspect of human intelligence. EQ is specifically related to human ability to control and manage their emotions and feelings in difficult situations.

\section{Critical Thinking}

Literature is a good medium for critical thinking enhancement among language learners (Gajdusek \& van Dommelen, 1993, Ghosn, 2002, Van, 2009). It can open "horizons of possibility, allowing students to question, interpret, connect, and explore" (p. 607). Literature among other text types is fertile with ideas to critically look at. Here the role of the teacher is very significant in developing such higher-order thinking skills. Today, critical thinking is the cornerstone of education particularly at advanced levels of education. Critical thinking prepares us not to take things for granted and to attempt to unravel the hidden agenda of texts.

To sum up, there are nine benefits of using literature offered in teaching English. It is able to promote students' motivation, cultural and intercultural awareness, intensive and extensive reading practices, sociolinguistic and pragmatic knowledge, grammar and vocabulary mastery, language skills, emotional intelligence, and critical thinking. At last, its authenticity allows the students to know the real use of such language in communication.

\section{METHODS}

Despite a number of studies have proven that the use of literature is beneficial, on contrary this research found the facts that the English teachers of junior high schools in Tanah Datar regency face obstacles to conduct their teaching by using literature.

The data were gained and analyzed within a qualitative research paradigm. The data were collected through interviewing the informants who were 10 English teachers who had ever used or integrated literature in their teaching. In order to maintain the data trustworthiness, the information was crosschecked within each other. Some informants were interviewed twice to confirm and clarify their previous information. The interviews were terminated as the data saturated, no more new data gained.

\section{Factual Obstacles Found in the Classroom while Integrating Literature}

Based on the analysis of the data, there are nine types of teachers' obstacles while using or integrating literature in their 
classroom. The findings are exposed in detail as follows:

\section{1) Literature has difficult language}

According to Richards in Aghagolzadeh (2012:208) the problem that counts for authentic materials, like literature, is its difficult language, complex language structure and unneeded vocabulary. In addition Berardo (2012:208) states that the biggest problem with authentic material is that if the wrong type of text is chosen, the vocabulary may not be relevant to the learner's needs and too many structures can create difficulty.

It is relevant with the research findings. After analyzing the data, the researcher found that one of the teachers' difficulties in integrating literature in their teaching is literature has difficult language. It can be seen from the interview result from informant $1,4,8,9,10$,

Based on interview with the informant I1, it was found as:

I-1 : Aaaa... kendalanyaaa kalau song ndak gitu banyak, anak-anak banyak yang suka, Cuma kendala.....kendala bahasanya, pronoun-nya, kalau anak-anak disuruh menyanyikan lagi itu kan (U-5)

[When I used song, the students were mostly eager to study, but the problems.... its language, and the way they pronounced the lyrics

I-4 : biasanya pada tingkat anak SMP nyanyi itu menarik untuk mereka, dan kebanyakan mereka suka nyanyi kecuali ibuknya, saya kurang bisa. Tapi kadang nyanyi itu tidak sesuai dengan level anak SMP, jadi kadang saya pilah mana yang bisa untuk mereka mana yang tidak sesuai dengan topik dan levelnya. Kalau poetry itu bagus tapi saya tidak pernah menggunakannya,karena bahasa antara kamus dan puisi itu berbeda. Kalau masalah drama, dulu dua tahun yang lalu ada tapi sekarang tidak, karena kemampuan anak dan waktunya. $(U-5)$

[Usually SMP students like singing, most of them like songs except me hmm, I can't . But sometimes the songs are not suitable for them. So I sometimes select a song which suits their ability, the topic and level. Poem is good too, but I never use it, because between the language in dictionary and that of poem is different. Two years ago I used drama in my teaching, but not now, due to students' limited ability and time.

Accordingly, the teachers used songs in their classroom, however through the interview it reflects that the teachers' difficulties while integrating the literary work was due to its language. Moreover, while having been confirmed, even the teachers themselves found that the language was complicated to understand. Besides, the informants argued that the language found in the literary works was poetic, and they rarely found and used such kind of language daily. It might be in terms of unfamiliar diction, and its level, as mentioned below:

I-4 Vocabnya apa lagii, hahahaha.... Iya iya, vocabnya yang paling susah. Song itu kan bahasanya bahasa sastra, sulit dimengerti.(U-6)

[its vocabulary is even the toughest. The language of the song, being a poetic language, is diffificut to comprehend.]

I-8 Saya kan mengajar di kelas 9... disitu susah mencari lagu yang cocok. Dak mungkin lagu cinta-cinta ..ehehehe. kosa katanya banyak yang tidak sesuai.

[I am teaching grade 9, so it is hard to find the suitable song, impossible to have a love song, of course. The vocabulary level does not suit the students).

It is noticable that language of literature is poetic in terms of diction and structure. It causes difficulties to the English teachers to use it in their teaching. Then, the informants specifically argued about the choice of words. Many English songs can not be used in teaching English for junior high students because they mostly talked about love which is culturally and psychologically not yet suitable for the students.

In addition, the informants found obstacles in integrating literature in their English teaching because of the vocabulary. 
All of the informants agreed that the vocabulary is very difficult to comprehend.

I-8 Mmmm yaa Kalau kesulitannya hampir sama dengan cerita tadi, mungkin ooo apa tu namanya sulit untuk ooo pronunciation,vocabulary, dan susah untuk menyesuaikan dengan kemampuan siswa, jadi nampaknya setelah dicoba nampaknya ini lebih baik untuk kelas yang lebih tinggi.

[The problem is pronunciation, vocabulary, and difficulties to suit with students' ability, it is suitable for upper level students, perhaps].

I-9 Ya pasti ada kesulitan, karena ooo Bahasa Inggris kan bahasa asing gitu kan, terus aaa kalau di siswa tingkat SMP ini kan mungkin dia ada siswa itu yang baru belajar Bahasa Inggris saat baru masuk SMP, ada juga yang udah belajar dari SD, bagi siswa yang tidak belajar saat SD itu dia merupakan kendala bagi dia, kendala secara umum bagi guru Bahasa Inggris yaitu tentang kosakata atau vocabnya.

[Of course we have a problem, because English as a foreign language is a new thing for most students of junior high school. Mostly teachers get problem with its vocabulary].

Those results of interviews describe the teachers' obstacles in integrating or using literature while teaching English in junior high schools. Almost all of the informants argued that the language of literature, in terms of its structure, diction, and vocabulary are difficult to understand by the students, even by the teachers themselves. Being poetic and connotative, sometimes the teachers can not find the meanings of the certain expressions in a dictionary whose meanings are denotatively explained.

Junior high schools students have a very limitied vocabulary and difficulti to pronounce the English words properly. Hence, when the teachers used songs, poetry, short stories, and dramas, it is suggested to begin their lesson by asking the students to practice using the words in advance. Make sure they are already familiar with the vocabulary and know how to pronounce it firstly, then the teachers can come to the next activities.

\section{It is difficult to choose literature suitable with the students' level.}

Lazar (1994:115) states that there are three difficulties in using literature. They are: language grading, literary competence, and motivation. It is relevant with the research findings, based on the result of interview that to choose literature suitable with the students' level is one of teachers' difficulties in using literature. It is indicated by the responses of the informants $1,2,4,5$, and 8 , as follows:

I-1 Yaa saya pernah menggunakan song, saya pikir sudah OK, tapi yaa. Levelnya masih tinggi. Siswa banyak dak paham gitu.

[I used song once, I thought the song is ok, but in fact it was not at my students' level. It was too hard to understand]

I-2 Kesulitan lebih ke.. pemilihan materi, karena ooo..short story itu ada beberapa ooo kosakata-kosakata yang mungkin susah untuk dipahami oleh siswa. Jadi dalam pemilihan materi itu kita lihat juga levelnya, apakah materi tersebut terjangkau oleh siswa atau tidak. Jadi lebih kepemilihan materi dan tingkat kesulitannya.

[The difficulty is due to choosing learning material because, for example short story, it has difficult vocabulary. So, to select the literature for students we should pay attention to the level. The teacher should at first know the level of difficulties]

As noticed from the interview results, the teachers got difficult in selecting the literary works for their students because many of the works do not suit the students' level. Eventhough the teachers have tried to choose the easiest ones, the students still were confused. The fact that English is not taught in elementary school makes it strange for the students. The students' English ability is severely low.

Besides dealing with the content, the teachers were difficult to train the students' pronunciation. They stated that songs, even the slow ones, are still too speedy for the students to follow, as told below:

I-5 Saya lihat siswa saya suka ... mereka bersemangat kalau saya pakai song. .. I Have a Dream Westlife mereka suka...tapi terlalu 
cepat juga. Entah apa yang heheh mereka ucapkan....

[I saw my students loved and were motivated when I taught them with a song. They liked "I Have a Dream" by Westlife, but still too fast for them to follow].

I-8 Mother.. itu kan lagunya slow kan, pelan gitu. Saya jadikan eee seperti puisi.Tapi anak-anak masih komplen... mereka susah membaca liriknya, tulisannya beda gitu. Salah-salah mereka pengucapannya.

["Mother" a title of a song by Dolly Parton. It is slow. I asked my students to read the lyrics, like the way we read a poem. They still complained that the lyrics were unfamiliar and difficult to say because they had to read differently from the way it was written].

It is known that the teachers have efforted to find as suitable as possible the literary works for the students. Initially, they thought it would be good enough, but in fact it is not. Based on this, it is found that the obstacles of integrating or using literature in English class because the work's level is not suitable with the students'. The difficulties may be in terms of content, speed, and pronunciation.

\section{2) Difficult to choose literature suitable with the topic.}

Gonzalez in El-Helou (2010:68) states that most EFL teachers know how difficult using literature in teaching language. It is to get students to achieve fluency in English. This is mainly due to large classes, limited time, students sharing the same mother tongue, and inappropriate use of materials and/or methodology.

It is relevant with research findings, based on the result of interview. The teachers are difficult to choose literature that is suitable with the topic. Based on the research findings, it is stated by the informants 2,3 , and 6 , as follows:

I-3 Kalau short story itu kebetulan dipakai pada materi kelas delapan teks naratif untuk listening, speaking, reading, writing, itu kebanyakan kita menggunakan short story. Bisa juga dibantu dengan media gambar.
Kalau topik atau teksnya selain itu, susah mencarikan literature nya.

[Short story can be used to teach narrative text at grade 8. It can be used for listening, speaking, reading, and writing. Unfortunately, literature is hardly used to teach other topics.]

I-6 Apa ya...descriptive text pakai song, ndak mungkin...apa ya lagunya. Puisi... saya sendiri dak begitu bisa hehehe.. susah kayaknya menyesuaikan dengan topiknya.

[Well, it is impossible to teach descriptive text with a song. Poetry.. I don't even undestand it.. it seems difficult to adjust literature with the topics.]

Based on the interviews, the teachers have no ideas to link literature with the topics, except the narrative text. On the other occasions, the teachers said that actually they are fond of using literature in teaching English, but they do not possess much knowledge about literature in English language teaching. Therefore, the fact causes the teachers' difficulties to adjust literature with the topics to be taught.

\section{3) Difficult to manage the time}

According to Gonzalez in El-Helou (2010:68) that most EFL teachers know how difficult using literature in teaching language. It is to get students to achieve fluency in English. This is mainly due to large classes, limited time, students sharing the same mother tongue, and inappropriate use of materials and/or methodology.

The research findings show that the teachers are difficult to manage time while using literary works in teaching. It is declared by informants $3,4,8,10$ as the followings:

I-4 Kalau masalah drama, dulu dua tahun yang lalu ada tapi sekarang tidak karena kemampuan anak dan waktunya.

[I used drama once, but not now because of the students' low ability and time management].

I- Idealnya, song itu.... kan diputar dua atau tiga

10 kali. Tapi anak-anak ini...sudah diputar berkalikali, masih minta diulang lagi. Habis waktu untuk saja. 
[Ideally, in listening session, the song was played twice or three times. In fact, my students asked to play several more times. It wasted time].

As the result of the interviews, it is found that integrating literature in teaching English is time consuming. Due the problem of time management, the learning goals can not be achieved well. Related to the time management obstacle, the teachers also exposed as follows:

I-3 Iya, pernah, kalau untuk short movie itu kesulitannya yang pertama yaitu persiapan awal, kalau persiapan awal kita menggunakan ooo... apa in focus tentu ada apa? Ooo membawa kabel, ooo menghubungkan apa, menghubungkan apa? ke slot-slotnya, kabel-kabel itu ke slotslotnya, jadi butuh waktu, jadi bisa saja nanti untuk proses PBMnya waktu yang disediakan mungkin aaa banyak terpakai untuk hal-hal yang di awal itu. Hmm mmm(U-2)

[The difficulty in using short movie was about preparation. We needed to bring in focus, cables, and then connect them to the slot. We needed more time to prepare it. So it spent more time for teaching learning process]

I-8 Ya... drama memang good for speaking, tapi penampilan drama...anak-anak tu kan banyak, jadi untuk mencek kemampuan mereka satu kelas butuh waktu. Jam pelajaran bahasa Inggris kan 2x40 menit, susah menetapkan waktunya.

[To perform a drama takes very much time to prepare, since we have to check the students' readiness wholy, meanwhile the time is limited to $2 \times 40$ minutes]

According to the teachers, using literature in the classroom makes them difficult to manage the time because it takes much more time to prepare. They believe drama is good to improve students' speaking skill, however it takes time to use prepare the drama performance. Besides, it is a problem to prepare the tools to teach drama or movie to the class. The teacher must be sure of the electric connectivity and other stuffs.

In conclusion, the teachers get problems in terms of time management to integrate literature in English classroom. The teachers are difficult to set the time because of the students' lack of ability, having a big class, and checking the property to prepare.

\section{4) Students' lack of pronunciation}

As mentioned previously, the students' lack of pronunciation is one of the most teachers' difficulties in using literature in English classroom. In line with other language skills, the students are not able to pronounce the English words well. Eventhough the students enjoyed studying English through songs and drama, the teachers still worked harder to make the students understand the materials. As the teachers (informants 1, 8, and 10) state below:

I-1 Kendalanya ... kalau song ndak gitu banyak, cumaa anak-anak mungkin, kalau disuruh mengikuti kemudian, kendala bahasanya, pronounnya, kalau anak-anak disuruh menyanyikan lagi kan.

[I don't find any serious problem while using song. Just if the students are asked to repeat the song, they are confused about how to pronounce the words].

I-8 Mmmm yaa kalau kesulitannya hampir sama dengan cerita tadi, mungkin ooo apa tu namanya sulit untuk ooo pronunciation, vocabulary, dan susah untuk menyesuaikan dengan kemampuan siswa. Mereka mengeluh, tulisannya berbeda dengan cara membacanya [The students are confused about pronouncing the words, they complained because the writing is not the same with its pronunciation].

Moreover, she also states that,

Aaa yaa itu dia, pada keterampilan membaca, mereka membaca satu paragraf saja, minta ampun lamanya. Karena mereka kelas satu, kosakata mereka tu masih sedikit, vocabnya, cara membacanya, aaa itu yang, jadi butuh waktu yang banyak dan susah me-manage waktunya.

[Their reading skill is low. I need extra time to fix their pronunciation. Therefore, it is difficult to manage the time.]

From the interview and observation result, it is noticable that students' lack of pronunciation ability is one of teacher 
difficulties in using literature. Due to the current curriculum, English is no more introduced to the elementary students. The students in junior high school treats English as a relatively new thing. The difference between the way it is written and that of it is spoken makes the students confused.

\section{5) Unavailable supporting tools such as monitor, drama properties, and sound system.}

According to the teachers, the absense of supporting tools becomes an obstacle for the teachers to use literature in their class. As the informants 5,6,9, and 10 reported;

I-5 Eee saya pernah putarkan film, tapi yaa.. in focus,ya sarana tidak mendukung. Speaker saja saya bawa sendiri dari rumah... di sekolah, ada, tapi yaa dak cukup, ada yang rusakjuga

[I ever used a movie, but the tools to support, such as loud speaker and monitor were not availabe. I just brought my own speaker]

I-6 Semester kemaren anak-anak main drama, judulnya aa Thumbellina, itu di.. diambil dari teks naratif. hehehe...mereka asik walau persiapannya eee lumayan lama. Mereka senang... tapi.. aa propertinya susah mengadakannya... rata-rata mereka bawa dari rumah masing-masing.. ya

[My students played a drama, the title was Thumbellina, taken from a narrative text. They were happy though we had such a long time for preparation. The problem was lack of property.... they had to some of the properties from home]

Based on the interview results, it is found that the teachers actually were eager to use literature in their class, however they found some obstacles related to lack of supporting properties. They creatively asked the students to provide themselves eventhough sometimes it caused another problem as the following interview result:

I-8 Aa ya..waktu itu anak-anak ini mencari bambu untuk penampilan itu... yaa.. tiga hari menjelang aa tampil itu, hujan lebat waktu itu, kalau ndak salah... anak itu jatuh, kakinya luka cukup dalam.
[Three days before the drama performance, I asked the male students to find bamboos. It was a heavy rain, if I am not mistaken, One of them felt down and got his leg injured seriously]

I-10 Dua hari ... ee sehari sebelum drama perform kami suruh anak-anak membawa... bambu, kain ...kain panjang itu, untuk pentas ya.. hehehe dak taunya kain panjangnya robek, hehehe sampai kami ditelepon wali murid itu..hehehe. Mungkin untuk yang seperti-seperti ini, kita butuh ruangan khusus lah ya...

Kalau anak-anak bernyanyi ya... suaranya mengganggu kelas sebelah.... jadinya yaa.. anak-anak itu dak pula konsentrasi kan..

[A day before the performance the students were asked to bring bamboos, long batik clothes to decorate the stage...unfortunately one of the clothes was torn. The parent was a little upset and called me. Well, it seems if we want to have literature like drama, or song, a special room and properties are needed. While we were singing, the nextdoor teacher complained that the sound was disturbing]

Those findings prove that the lack of supporting facilities can cause trouble for students as well as the teachers. Those facts were not supposed to happen if the school would have provided the facilities. The need of a special room has been claimed by the other teachers. They found that their collegues were often complained about the noise while the students were practicing with literature.

\section{6) Difficult to get the resources}

Based on the result of interview, the teachers are difficult to get the literature to use. They have got the materials just from internet. Here are the results of the interview with some of the teachers, as Informants 1, 2, $4,5,6,7$, and 9 as follows:

I-1 ...saya hanya ambil di internet....sekalian kan ada teksnya.hehe..

[I just download from internet....the text and lyrics are provided also] ...ya...saya download dan berikan ke siswa.... [I downloaded and gave it to my students]

I-2 Bahan literature? Ya...aa saya download dari internet... kalau buku kan ndak ada lah...ya...susahlah.. 
[Literary works? I don't find the books, so I just search from internet]

I-5 Kalau lagu-lagu untuk anak-anak banyak di internet....sekalian teksnya kan....ada videonya kadang. Cerita..dongeng juga dari internet.....banyaklah.

[I have the songs, the children songs from internet, as well as the stories...there are lots of them]

Based on the interview results, almost all of the teachers take the literary works from internet, however they do not mention the website. They just used the search engine by writing the key words "children songs", and many songs appeared on the screen. They selected the songs they considered interesting for their students. It seems they have taken the materials without further consideration, such as the length, the level of difficulties, and so on.

\section{7) Unattractive poem material}

Among the kinds of literature, the teachers found the poem is considered to be boring and unattractive for the students. This becomes an obstacle because this kind of literature has complicated language structure which is rarely taught and used by the teachers in their class. The statements were uttered by informants 5 and 10 .

I-5 Poetry ituu, aaa kalau dibandingkan dengan song yaa, poetry itu agak kurang menarik bagi siswa, a a a soalnya dalam sehari-hari kan jarang. Cuma yang berbakat seni gitu...baru bisa menarik bagi dia.

[Comparing with songs, poetry is less attractive, because it is rarely found and used in students' daily life.]

I- $\quad$ Saya melihat anak-anak tidak tertarik kalau

10 belajar puisi itu... yaaa ada yang minta permisi, ngobrol mereka kan.... susah mungkin. Tapi kalau nyanyi hmm mereka semangat tu.

[I think the students do not like learning with poetry. They were not motivated, perhaps because it is complicated. They like songs very much.]

\section{Students' unconfidence}

Based on the result of interview, to assess the learning output or to make variation the teachers often asked the students to do performances. They were asked to sing the song, to recite the poem, or to act in front of their friends. Unluckily, the students were not confident. They were shy and tried to avoid. As the informants 3 and 7 stated:

I-3 Biasanya ooo siswaaaa ooo untuk setelah oo kita menyaksikan kan, mereka tu mencobakan nyanyi bersama-sama dan di saat itu mereka mengeluarkan suara itu malu-malu.

[Usually when I asked them to sing together, they did not do it well. They were shy to sing loudly]

I-7 Sudah dilatih dan diajarkan berulang kali yaa tetap juga ndak keluar suaranya....eeh ada yang pura-pura sibuk hehehe pura-pura ndak mendengar lah yaa..

[I had them to practice the song and read the lyric many times but they still sang soundlessly, some of them pretended to do something else or not hear when I asked them to the front]

Though the students enjoyed learning with literature, they were mostly shy and avoided to perform their skill in front of their friends. It might be said that the students' unconfidence causes obstacles in integrating literature in English class.

\section{DISCUSSION AND CONCLUSION}

Based on the research findings, there are nine obstacles faced by the junior high English teachers while integrating literature in their teaching. They are: 1) Its difficult language, in terms of its complexity, its structure, vocabulary, and poetic and unfamiliar diction, 2) inappropriacy with the students' level, 3) not suitable with the topics, 4) time management, 5) students' lack of pronunciation, 6) unavailable supporting tools, 7) limited resources, 8) students' unconfidence, and 9) unattractive poem material.

Among the findings, the literature's language becomes the biggest problem found by the teachers while integrating the 
literature in their teaching. In line with McKay in Aghagolzadeh (2012:208) that the non standard use of language and its complex structure lead to the biggest problem particularly if the wrong type of text is chosen. Based on the interview results all of the teachers argued that even they who brought the texts into the class, could not catch the meaning of some parts of the literature. Practically, before bringing literature into the class, it is suggested that the teacher possesses basic knowledge of literature and how to use it in English for languageteaching context. There have been hundreds resources available online, however she/he should select the appropriate texts. It is suggested to pay attention to the choice of words, length, level of difficulties and time available. Maintaining the literature's origin is alright, but in this case, the teacher should not merely take the text and bring it to the class as it is. Besides adjusting the text with the students' needs, for the very low level students, it is recommended to create or improvise the literature by her/himself.

\section{REFERENCES}

Aghagolzadeh, Ferdows. A Debate on Literature as a Teaching Material in FLT. Vol. 3, No. 1, January 2012. Available

on www.academypublication.com Retrieved on December $29^{\text {th }} 2014$.

Arsyad, Azhar. 2011. Media Pembelajaran. Jakarta: Rajawali Pers

Asha Rai. 2012. Use of literature in Teaching English. International Journal and Education of Research. Original Article. Vol 3 Available on www.soeagra.com/ijert/ijert.htmv

Retrieved on May, $13^{\text {th }} 2015$

Brown, H. Douglas. 2007. Teaching by Principles " An Interactive Approach to Language Pedagogy". New York: Pearson Education Inc.

Brown, D. 1994. Principles of Language Learning and Teaching. New York: Pearson Education Company

Brumfit, C. (2001). Individual Freedom in Language Teaching. Oxford: Oxford University Press.

Crawford, Alan. 2005. Teaching and Learning Strategies for the Thinking Classroom. New York: The International Debate Education Association.

Duff, A. and Maley, A. 2007. Literature. (Second edition). Oxford: Oxford University Press.

Gay, LR, and Peter Airasian. 2000. Educational Research (Competencies for Analysis and Application). USA: Merril Publishing Company.

Hadaway, N. 2002. Literature-Based Instruction with English Language Learners, K-12. Boston: Allyn and Bacon.

El-Helou, Rabah Ali Hani. 2010. Difficulties Facing English Teachers in Teaching Literature in English for Palestine Grade Twelve Textbook. The Islamic University - Gaza

Khatib, Mohammad. Literature and Language Teaching. Vol. 2, No. 6, June 
2012. Available on www.academians.org retrieved on December $29^{\text {th }}, 2014$

Lazar, G. 1994. Using Literature at Lower Level: A Guide for Teachers and Trainers. Oxford: Oxford University Press.

Lewis, C.S. 2010. How Literature can Influence the English Language Learning. Available on hlcitll/funiblogs.com Retrieved on January 15,2015

Longman Dictionary of Contemporary English. 2003. UK: Pearson. available on http://www.teachingenglish.org.uk/article/usi ng-literature-introduction . Retrieved on march $14^{\text {th }}, 2015$.

Parkinson, B., \& Reid Thomas, H. (2000). Teaching Literature in a Second Language. Edinburgh: Edinburgh University Press.

Ruis, Nuhung. 2009. Instructional Media. Jakarta: Ministry of National Education. Available on http://www.InstructionalMedia.com Retrieved on January $13^{\text {th }}, 2015$

Shazu, Islam R. 2014. Use of Literature in Language Teaching and Learning: A
Critical Assessment. available at www.iiste.org Vol. 5, No. 72014 Retrived on December $29^{\text {th }}, 2014$.

Savvidou, C. (2004). An Integrated Approach to the Teaching of Literature in the EFL Classroom. The Internet TESL Journal, 12. Available on http://iteslj.org Retrieved February $18^{\text {th }}$, 2015

Tehan, Patricia. 2015. The Place of Literature in An English Language Teaching Program: What Do Students Think About It?. The Reading Matrix: An International Online Journal. Volume 15, Number 2, September 2015. Available on http://www.readingmatrix.com. Retrieved December $18^{\text {th }}, 2015$

Turker, F. (1991). Using Literature in Language Teaching. Hacettepe Universitesi Egitim Facultesi Dergisi6, 299-305. Available on dergipark.ulakbim.gov. Retrieved on December $18^{\text {th }}, 2015$

www.ccsenet.org/elt English Language Teaching Vol. 4, No. 1; March 2011 Published by Canadian Center of Science and Education 203 